\title{
Vaccine-induced thrombotic thrombocytopenia (VITT): first report from India
}

\author{
Christy V. John, Rajesh Kumar, Anil Kumar Sivan, Sangeetha Jithin, Rojin Abraham and Chepsy C. Philip* (D)
}

\begin{abstract}
Background: Vaccine-induced thrombotic thrombocytopenia (VITT) is a rare but devastating adverse event following adenoviral vector-based vaccinations for COVID-19, resulting in thrombosis, especially of the cerebral and splanchnic vasculature. Despite the progress in laboratory techniques for early diagnosis, VITT remains a clinical diagnosis supplemented by coagulation studies. We report on VITT for the first time from India.

Case: We describe cortical venous sinus thrombosis and intracerebral bleed associated with severe thrombocytopenia in two young men who had no other contributory cause besides a recent ChAdOx1 nCoV-19 vaccination. The diagnosis was supported with PF-4 antibodies in one patient. The second patient's test could not be processed to technical limitations. Both patients were treated with IVIG at $1 \mathrm{~g} / \mathrm{kg}$ for 2 days and anticoagulation (Apixaban). One patient fully recovered with no residual deficits, and the other is under treatment and recovering.

Conclusion: VITT can cause devastating fatality and morbidity in otherwise healthy patients via potential immunemediated effects. Clinicians should have a high suspicion index and treat VITT in the appropriate setting even if the PF-4 antibody testing by ELISA is unavailable or delayed. Though counterintuitive, clinicians must not delay the administration of non-heparin anticoagulation, IVIG and restrict platelet transfusion even in the presence of intracerebral haemorrhage.
\end{abstract}

\section{Background}

Vaccine-induced thrombotic thrombocytopenia (VITT) is a rare but devastating adverse event following the administration of adenovirus-based vaccines, namely the ChAdOx nCoV-19 (Astra Zeneca) and the Ad26.COV2.S (Janssen) [1-3]. The reported cases of VITT from countries with limited resources continue to be scarce despite massive vaccination campaigns. Here we report VITT for the first time from India in two previously healthy young men with prior normal platelet counts who presented with thrombocytopenia, intracerebral bleed, and cerebral venous thrombosis. Delay in diagnosis and instituting appropriate treatment could have been fatal. Both

\footnotetext{
* Correspondence: chepsyphilip@bcmch.edu.in

Clinical Haematology \& Bone Marrow Transplantation, Believers Church

Medical College Hospital, Thiruvalla, Kerala 689103, India
}

had a favourable outcome on therapy in a limited resource setting without rapid access to confirmatory testing for PF4 antibodies.

\section{Case 1 \\ A previously healthy 25 -year-old male had presented to the emergency department with a history of a subacute onset, progressive headache evolving over the last 6 days. $\mathrm{He}$ had been evaluated elsewhere for his symptoms a day earlier. A computed tomography (CT) of the brain revealed a normal study and a hemogram that reported thrombocytopenia with a platelet count of $6 \times 10^{9} / \mathrm{L}$. He had no risk factors or suggestive family history for a thrombotic event. He had received the first dose of the ChAdOx1 nCoV-19 (AstraZeneca) vaccine 15 days prior (day of vaccination $=$ day $\# 0=\mathrm{D} 0$ ). On the day of}

(c) The Author(s). 2022 Open Access This article is licensed under a Creative Commons Attribution 4.0 International License, which permits use, sharing, adaptation, distribution and reproduction in any medium or format, as long as you give appropriate credit to the original author(s) and the source, provide a link to the Creative Commons licence, and indicate if changes were made. The images or other third party material in this article are included in the article's Creative Commons licence, unless indicated otherwise in a credit line to the material. If material is not included in the article's Creative Commons licence and your intended use is not permitted by statutory regulation or exceeds the permitted use, you will need to obtain permission directly from the copyright holder. To view a copy of this licence, visit http://creativecommons.org/licenses/by/4.0/. The Creative Commons Public Domain Dedication waiver (http://creativecommons.org/publicdomain/zero/1.0/) applies to the data made available in this article, unless otherwise stated in a credit line to the data. 
presentation (D15), he developed a new-onset weakness of the left half of his body, progressing over the past few hours, evidenced by an inability to sit up from bed and difficulty gripping objects. Neurological examination confirmed a hemiparesis with a hemisensory loss with dysmetria and nystagmus localised to the left.

\section{Diagnosis}

Emergent Magnetic Resonance (MR) Imaging of the brain (Fig. 1) showed a right high parietal haematoma measuring $4.7 \times 2.3 \mathrm{~cm}$ with oedema and signs of micro haemorrhage in the left parietal lobe and cerebellar hemisphere. Computed tomographic (CT) angiography of the brain revealed extensive thrombosis of the superior sagittal and right transverse sinuses. D-Dimer (Supplementary Figure 1) was elevated $(6060 \mathrm{ng} / \mathrm{ml})$ with normal Prothrombin (PT) and activated partial thromboplastin (APTT) time. Testing for antibodies to platelet factor 4 (PF4) was done using a chemiluminescence immunoassay (CLIA) which was negative. Due to the high index of suspicion, it was followed up with Enzyme-Linked Immunosorbent Assay (ELISA) for confirmation of PF4 antibodies. The sample degenerated in transit and was not reported (Test was couriered offsite with a turnaround time of 4 weeks).

\section{Management}

He was managed conservatively. Given the intracerebral haemorrhage (ICH); he received platelet transfusion on admission. With a high index of suspicion, he was initiated on high dose Intravenous Dexamethasone $40 \mathrm{mg}$ (HDD) with Intravenous Immunoglobulin (IVIG) at a dose of $1 \mathrm{~g} / \mathrm{kg}$ body weight over $24 \mathrm{~h}$. A similar dose of IVIG was administered the following day. He was initiated on anticoagulation with Apixaban $2.5 \mathrm{mg}$ twice daily (in view of thrombocytopenia and the perceived increased risk of bleeding). Despite initial neurological deterioration with motor aphasia and left facial palsy, the dose was incremented to $5 \mathrm{mg}$ twice daily over the next $48 \mathrm{~h}$.

\section{Follow-up}

Over a week, he demonstrated significant clinical improvement corroborated by a brain $\mathrm{CT}$, which showed no signs of haematoma expansion. He demonstrated near-complete resolution of neurological deficits and was self-ambulatory on discharge with the total dissolution of the thrombosis on repeat CT angiography. He remains well on Apixaban with a normal hemogram on follow-up.

\section{Case 2}

A 19-year-old male with no significant medical history was brought to the emergency department after being found in an unresponsive state in his bedroom (D8). His parents recalled his headache for the past 4 days (D5D8), for which he was evaluated elsewhere with a CT of the brain, which was normal and was given symptomatic care. He had no risk factors or suggestive family history for a thrombotic event. He had received his first dose of ChAdOx1 nCoV-19 (AstraZeneca) 8 days before the onset of symptoms (D0).

\section{Diagnosis}

Emergent CT imaging of the brain revealed gross hematoma in the bifrontal region. MR Venogram (Fig. 2) confirmed a superior sagittal sinus thrombosis. Laboratory investigations (Supplementary Figure 1) showed thrombocytopenia $\left(4.2 \times 10^{\wedge} 9 / \mathrm{L}\right)$ and elevated D-Dimer (7760 ng/ml). PT \& APTT were normal. Initial testing

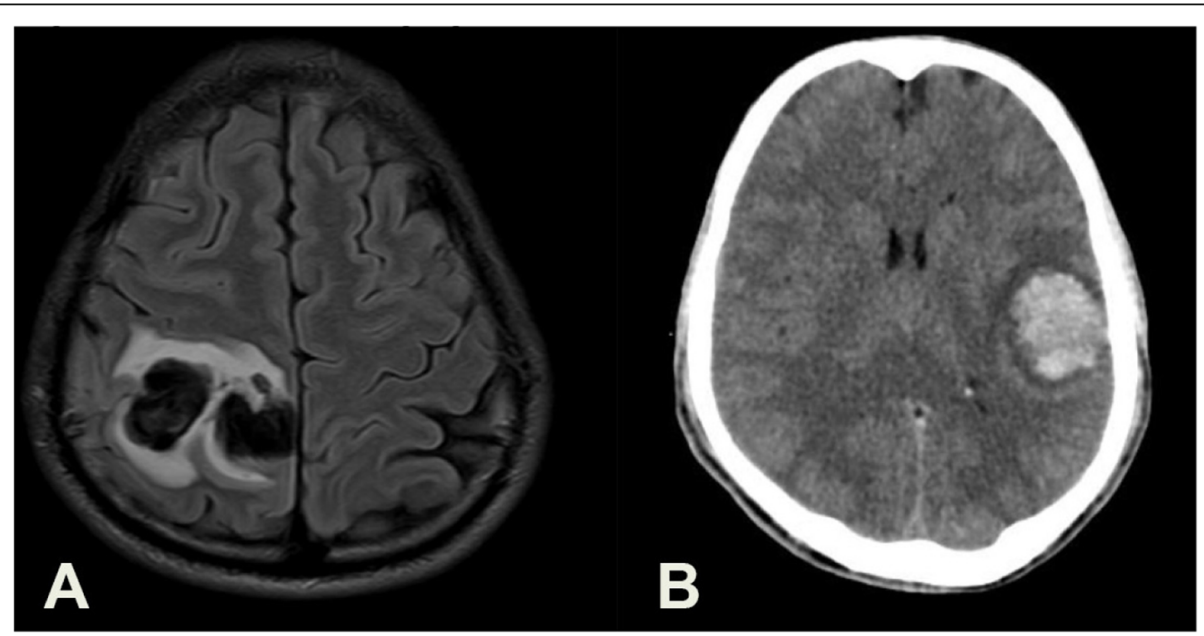

Fig. 1 Case 1 Neuroimaging. A: Axial FLAIR MR image -right high frontoparietal hematoma $(4.7 \times 2.3 \mathrm{~cm})$ with oedema. B: Plain CT image worsening with a new hematoma in the left parietal lobe $(4.3 \times 3.3 \mathrm{~cm})$ 


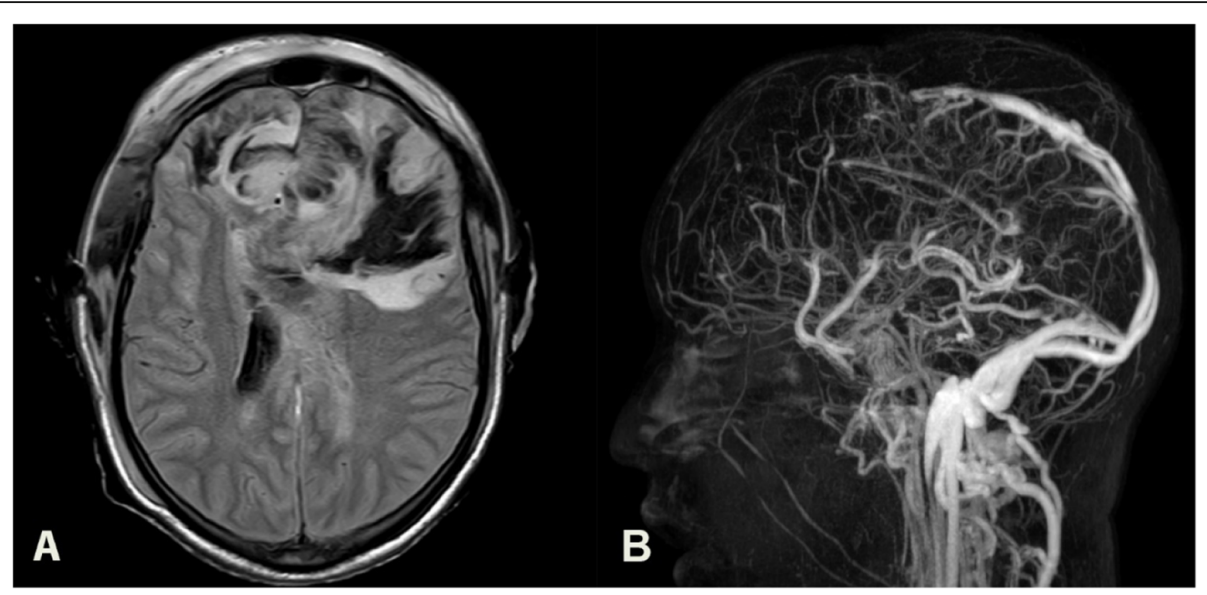

Fig. 2 Case 2 Neuroimaging. A: Axial MR image -bilateral frontal lobe extensive haemorrhage with intraventricular extension. B: MR Venogram showing filling defects in the anterior half of the superior sagittal sinus

for anti-PF4 antibody by CLIA was negative, and blood samples sent for confirmatory testing by ELISA were reported positive after 2 months (Supplementary Fig. 2).

\section{Management}

He underwent a life-saving decompressive craniotomy on admission under cover of platelet transfusion with continued post-operative care. Proceeding with a high clinical suspicion of VITT, he was initiated on HDD with IVIG at a dose of $1 \mathrm{~g} / \mathrm{kg}$ body weight within $48 \mathrm{~h}$ of hospitalisation, with a repeat dosing a day later. He was anticoagulated with Apixaban $5 \mathrm{mg}$ twice daily. Over the ensuing 3 days, there was an increment in platelet counts to normal levels without any worsening of any neurological deficits.

\section{Follow-up}

His recovery was complicated by ventilator-associated pneumonia (VAP), bilateral pneumothorax and an extended weaning period with multiple healthcareassociated infections (HAIs) requiring cessation of anticoagulation. However, he is recovering and on follow-up post cranioplasty and is currently on an aggressive physical rehabilitation regimen.

\section{Discussion}

VITT is a rare but devastating adverse event following adenoviral vector-based vaccinations for COVID-19. The most commonly reported symptoms include persisting sudden onset headache, which may be associated with bleeding manifestations and could progress to gross neurological deficits, with an altered mental state $[4,5]$. Though majorly reported in unusual anatomic locations (cerebral and splanchnic veins), thrombosis could also involve deep veins, pulmonary embolism and acute arterial thrombosis [6-8]. VITT's estimated risk is at least
1:100,000 among patients 50 years of age or older and at least 1:50,000 among patients in the younger group [9]. The risk is amplified in younger individuals and recipients of the first dose.

Proposed pathogenetic mechanisms describe a process similar to the autoimmune Heparin Immune Thrombocytopenia (HIT) implicating tetramers of PF4 that crosslink with vaccine proteins to form multimolecular aggregates [10]. The increasing reports of PF4/heparin antibodies in contrast to patients with cerebral venous sinus thrombosis before the COVID-19 pandemic support this mechanism [11]. However, the mere presence of PF4 antibodies need not necessarily imply thrombosis in either HIT or VITT $[12,13]$. The presence of EDTA in the vaccine possibly contributes to capillary leakage and dissemination of components in blood. These aggregates are recognised by the Immunoglobulin (Ig) G antibodies and the complement system leading to clustering of PF4 with resulting platelet activation. Cumulative reactions lead to the formation of neutrophil extracellular traps (NETs) with a pan cellular FcyIla receptor activation akin to HIT. This culminates in a massive coagulation system activation, leading to consumptive coagulopathy with significantly elevated D Dimer levels and hypofibrinogenemia [14]. In contrast to HIT, procoagulant platelets are inhibited by low heparin concentrations and augmented by the addition of PF4 in VITT [15].

Current reports and case definitions highlight the importance of laboratory evidence for VITT. The growing understanding of VITT has improved the assays' sensitivity, especially the novel PF4 induced platelet activation test (PIPA) being the gold standard in ambiguous cases with low positive or negative PF4 ELISA testing $[15,16]$. Although highly sensitive for HIT, rapid testing using CLIA, particle gel immunoassay (PaGIA), and lateral 
flow assay (LFA) is uniformly inadequate in the diagnosis of VITT [17, 18]. Heparin-induced multi-electrode aggregometry (HIMEA) is a rapid and straightforward alternative to functional assays, which may potentially be helpful in VITT [12]. The combination of a negative CLIA and a positive ELISA, as in our experience, is similar to reports where the administration of IVIG has not impacted the test, likely reflecting that IVIG does not inhibit the VITT binding to PF4 $[8,15]$.

India has delivered more than 300 million doses to those between 18 and 44 years of age, and the lack of reports on VITT is intriguing. The true incidence of VITT in developing countries is likely under-represented, possibly to stringent case definitions and inadequate laboratory testing facilities. Though the unprecedented rapidity of vaccine production has been integral to the timely response to COVID -19 [19], it is vital that the lack of universally available tests shouldn't limit surveillance. Therefore, we believe that the interim case definition proposed by the Brighton Collaboration aids in a clinical diagnosis in limited-resource settings despite inaccessibility to adequate laboratory services [20]. The cases we described could be categorised as probable VITT and definite VITT, respectively, as per the NICE guidelines and Level 1 TTS as the Brighton collaboration definitions.

Although current case definitions mandate PF4 testing by ELISA, similar to the recommendations in HIT, timely imaging and treatment must be instituted based on a clinical diagnosis and an individualised basis [21, 22].

\section{Strength \& Limitations}

The National Adverse Events Following Immunization (AEFI) Committee in India, which submits data to the Government, reported a total of 179 serious adverse events [no VITT; 3 intracranial bleeds] after the 1st of May [23]. This could be to underreporting of VITT due to lack of such specialised tests or a regional paradox. We recognise the limitations of case reports to generalize and to establish cause-effect relationship; but we report the first confirmed case of VITT from India and this could be of importance to public health and policymakers for this newly recognised entity.

\section{Conclusion}

This is the first report to the best of our knowledge on Vaccine Induced Thrombotic Thrombocytopenia from India with the largest vaccination drive in the world [24]. In our initial and limited experience, VITT typically presents in younger male patients with no prior comorbidities making the severity of illness alarming. While testing for PF4 antibodies adds more evidence to establish the diagnosis, clinicians, though counterintuitive, should not delay the institution of anticoagulation and IVIG while limiting platelet transfusions.

\section{Abbreviations}

AEFI: Adverse Events Following Immunization; ChAdOx: Chimpanzee (Ch) adenovirus-vectored vaccine (Ad), developed at the University of Oxford (Ox); CLIA: Chemiluminescence immunoassay (CLIA); CT: Computed Tomography; EDTA: Ethylenediaminetetraacetic acid; ELISA: Enzyme-Linked Immunosorbent Assay; Fcylla: Low-affinity receptor for the constant fragment (Fc) of immunoglobulin (lg) G; FLAIR: Fluid-attenuated inversion recovery; HAls: Healthcare-associated infections; HIT: Heparin-induced thrombocytopenia; HIMEA: Heparin-induced multi-electrode aggregometry; ICU: Intensive care unit; IV: Intravenous; IVIG: Intravenous Immunoglobulin; LFA: Lateral flow assay; MR: Magnetic Resonance; nCoV-19: Novel coronavirus 19; NETs: Neutrophil extracellular traps; NICE: National Institute for Health and Care Excellence; PaGIA: Particle gel immunoassay; PF-4: Platelet Factor 4; PIPA: PF4 induced platelet activation test; PT: Prothrombin time; APTT: Activated partial thromboplastin time; VAP: Ventilator-associated pneumonia; VITT: Vaccine-induced Thrombotic Thrombocytopenia

\section{Supplementary Information}

The online version contains supplementary material available at https://doi. org/10.1186/s12959-022-00370-6.

\section{Additional file 1.}

Additional file 2.

\section{Acknowledgements}

Anju Esthapan, Ann Susan, Reshma Pillai.

\section{Authors' contributions}

The authors confirm contribution to the paper as follows: Christy $V$ John: draft manuscript preparation, data collection, analysis \& interpretation. Rajesh Kumar: draft manuscript preparation, data collection, Analysis. Anil Kumar Sivan: data collection, analysis \& interpretation. Sangeetha Jithin: data collection, analysis \& interpretation. Rojin Abraham: data collection, analysis \& interpretation. Chepsy C Philip: study conception and design, draft manuscript preparation, data collection, analysis \& interpretation. All authors reviewed the results and approved the final version of the manuscript.

Funding

No funding source.

Availability of data and materials

Two supplementary figures attached as supplementary files.

\section{Declarations}

Ethics approval and consent to participate

The institutional ethics committee of the Believers Church Medical College Hospital approved and waived the need for consent (IEC/2021/09/240).

\section{Consent for publication}

The institutional ethics committee of the Believers Church Medical College Hospital approved and waived the need for consent (IEC/2021/09/240).

\section{Competing interests}

The authors declare no competing interests.

Received: 19 September 2021 Accepted: 17 February 2022 Published online: 04 March 2022

\section{References}

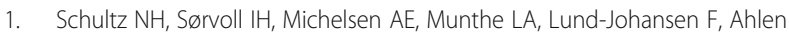
MT, et al. Thrombosis and thrombocytopenia after ChAdOx1 nCoV-19 vaccination. N Engl J Med. 2021:384(22):2124-30. https://doi.org/10.1056/ NEJMoa2104882. 
2. Greinacher A, Thiele T, Warkentin TE, Weisser K, Kyrle PA, Eichinger S Thrombotic thrombocytopenia after ChAdOx1 nCov-19 vaccination. N Engl J Med. 2021;384(22):2092-101. https://doi.org/10.1056/NEJMoa2104840.

3. Muir K-L, Kallam A, Koepsell SA, Gundabolu K. Thrombotic thrombocytopenia after Ad26. COV2. S vaccination. N Engl J Med. 2021; 384(20):1964-5. https://doi.org/10.1056/NEJMc2105869.

4. Salih F, Schönborn L, Kohler S, Franke C, Möckel M, Dörner T, et al. Vaccineinduced thrombocytopenia with severe headache. N Engl J Med. 2021; 385(22):2103-5. https://doi.org/10.1056/NEJMc2112974.

5. Rizk JG, Gupta A, Sardar P, Henry BM, Lewin JC, Lippi G, et al. Clinical characteristics and pharmacological management of COVID-19 vaccineinduced immune thrombotic thrombocytopenia with cerebral venous sinus thrombosis: a review. JAMA Cardiol. 2021;6(12):1451-60. https://doi.org/10.1 001/jamacardio.2021.3444.

6. Pottegård A, Lund LC, Karlstad $\varnothing$, Dahl J, Andersen M, Hallas J, et al. Arterial events, venous thromboembolism, thrombocytopenia, and bleeding after vaccination with Oxford-AstraZeneca ChAdOx1-S in Denmark and Norway: population based cohort study. BMJ. 2021;373:n1114. https://doi.org/10.113 6/bmj.n1114.

7. Cines DB, Bussel JB. SARS-CoV-2 vaccine-induced immune thrombotic thrombocytopenia. N Engl J Med. 2021;384(23):2254-6. https://doi.org/10.1 056/NEJMe2106315.

8. Bourguignon A, Arnold DM, Warkentin TE, Smith JW, Pannu T, Shrum JM, et al. Adjunct immune globulin for vaccine-induced immune thrombotic thrombocytopenia. N Engl J Med. 2021;385(8):720-8. https://doi.org/10.1 056/NEJMoa2107051.

9. Pavord S, Scully M, Hunt BJ, Lester W, Bagot C, Craven B, et al. Clinical features of vaccine-induced immune thrombocytopenia and thrombosis. N Engl J Med. 2021;385(18):1680-9. https://doi.org/10.1056/NEJMoa2109908.

10. Arepally GM, Ortel TL. Vaccine-induced immune thrombotic thrombocytopenia (VITT): what we know and Don't know. Blood. 2021; 138(4):293-8. https://doi.org/10.1182/blood.2021012152.

11. Sánchez van Kammen M, Heldner MR, Brodard J, Scutelnic A, Silvis S, Schroeder $V$, et al. Frequency of thrombocytopenia and platelet factor 4/ heparin antibodies in patients with cerebral venous sinus thrombosis prior to the COVID-19 pandemic. JAMA. 2021;326(4):332-8. https://doi.org/10.1 001/jama.2021.9889.

12. Morel-Kopp M-C, Mullier F, Gkalea V, Bakchoul T, Minet V, Elalamy I, et al. Heparin-induced multi-electrode aggregometry method for heparininduced thrombocytopenia testing: communication from the SSC of the ISTH. J Thromb Haemost. 2016;14(12):2548-52. https://doi.org/10.1111/jth.13 516.

13. Thiele T, UIm L, Holtfreter S, Schönborn L, Kuhn SO, Scheer C, et al. Frequency of positive anti-PF4/polyanion antibody tests after COVID-19 vaccination with ChAdOx1 nCoV-19 and BNT162b2. Blood. 2021;138(4):299303. https://doi.org/10.1182/blood.2021012217.

14. Greinacher A, Selleng K, Palankar R, Wesche J, Handtke S, Wolff M, et al. Insights in ChAdOx1 nCoV-19 vaccine-induced immune thrombotic thrombocytopenia. Blood J Am Soc Hematol. 2021;138(22):2256-68. https:// doi.org/10.1182/blood.2021013231.

15. Favaloro EJ. Laboratory testing for suspected COVID-19 vaccine-induced (immune) thrombotic thrombocytopenia. Int J Lab Hematol. 2021;43(4):55970. https://doi.org/10.1111/ijlh.13629.

16. Lavin M, Elder PT, O'Keeffe D, Enright H, Ryan E, Kelly A, et al. Vaccineinduced immune thrombotic thrombocytopenia (VITT)-a novel clinicopathological entity with heterogeneous clinical presentations. $\mathrm{Br} J$ Haematol. 2021;195(1):76-84. https://doi.org/10.1111/bjh.17613.

17. Vayne C, Rollin J, Gruel Y, Pouplard C, Galinat H, Huet O, et al. PF4 immunoassays in vaccine-induced thrombotic thrombocytopenia. N Engl J Med. 2021;385(4):376-8. https://doi.org/10.1056/NEJMc2106383.

18. Platton S, Bartlett A, MacCallum P, Makris M, McDonald V, Singh D, et al. Evaluation of laboratory assays for anti-platelet factor 4 antibodies after ChAdOx1 nCOV-19 vaccination. J Thromb Haemost. 2021;19(8):2007-13. https://doi.org/10.1111/jth.15362.

19. Makris M, Pavord S, Lester W, Scully M, Hunt B. Vaccine-induced immune thrombocytopenia and thrombosis (VITT). Res Pract Thromb Haemost. 2021; 5(5):e12529. https://doi.org/10.1002/rth2.12529.

20. Interim Case Definition of Thrombosis with Thrombocytopenia Syndrome (TTS) [Internet]. Brighton Collaboration. 2021 [cited 2021 Dec 16]. Available from: https://brightoncollaboration.us/thrombosis-with-thrombocytopeniasyndrome-interim-case-definition/. Accessed 16 Dec 2021.
21. Greinacher A, Langer F, Makris M, Pai M, Pavord S, Tran H, et al. Vaccineinduced immune thrombotic thrombocytopenia (VITT): update on diagnosis and management considering different resources. J Thromb Haemost. 2021; 20(1):149-56. https://doi.org/10.1111/jth.15572

22. Gruel Y, De Maistre E, Pouplard C, Mullier F, Susen S, Roullet S, et al. Diagnosis and management of heparin-induced thrombocytopenia. Anaesth Crit Care Pain Med. 2020;39(2):291-310. https://doi.org/10.1016/j.a ccpm.2020.03.012

23. AEFI Reports | Ministry of Health and Family Welfare | GOI [Internet]. Available from: https://main.mohfw.gov.in/Organisation/Departments-of-Hea Ith-and-Family-Welfare/immunization/aefi-reports. Accessed 20 Sept 2021.

24. CoWIN Dashboard [Internet]. Available from: https://dashboard.cowin.gov. in/. Accessed 5 Sept 2021.

\section{Publisher's Note}

Springer Nature remains neutral with regard to jurisdictional claims in published maps and institutional affiliations.
Ready to submit your research? Choose BMC and benefit from:

- fast, convenient online submission

- thorough peer review by experienced researchers in your field

- rapid publication on acceptance

- support for research data, including large and complex data types

- gold Open Access which fosters wider collaboration and increased citations

- maximum visibility for your research: over $100 \mathrm{M}$ website views per year

At BMC, research is always in progress.

Learn more biomedcentral.com/submissions 